УДК 342.52

DOI https://doi.org/10.51989/NUL.2021.6.14

\title{
ПЕРЕДУМОВИ ДЛЯ ФОРМУВАННЯ ПРАВОВИХ МЕХАНІЗМІВ ПРОТИДІЇ ДЕЗІНФОРМАЦІЇ В СОЦІАЛЬНИХ МЕДІА В КОНТЕКСТІ НАЦІОНАЛЬНОÏ БЕЗПЕКИ: ПОСТАНОВКА ПРОБЛЕМИ
}

\author{
Марущак Анатолій Іванович, \\ доктор юридичних наук, професор, \\ професор кафедри \\ Національної академії Служби безпеки України
}

У статті здійснено аналіз передумов для формування правових механізмів протидії дезінформації в соціальних медіа у контексті національної безпеки. Сформульовано висновок про необхідність формування таких механізмів на основі конституційних принципів свобода думки і слова із законодавчим закріпленням виключного переліку їх можливого обмеження в соціальних медіа задля забезпечення національної безпеки. Відзначено, що відмінність між правовими та внутрішньокорпоративними нормами регулювання діяльності компаній соціальних медіа безпосередньо впливає на ефективність захисту національних інтересів як США, так й України, оскільки незобов'язуючі норми Першої поправки Конституції США для приватних суб'єктів зумовлюють орієнтацію компаній соціальних медіа на отримання прибутку, хоча політика Facebook i Google й передбачає дотримання принципів свободи слова.

Зроблено висновок, що порівняно з урядом США український уряд має більш широкі конституційні передумови для захисту інтересів національної безпеки, зокрема, й у зв'язку з агресією Російської Федерації.

У контексті розбудови спроможностей Центру протидії дезінформації відзначено, що протидія дезінформаційним кампаніям з міркувань національної безпеки вимагає поєднання зусиль Центру як із суб'єктами національної системи кібербезпеки, так і з органами регулювання діяльності засобів масової інформації, підрозділами стратегічних комунікацій органів державної вади України в тісній співпраці з приватним сектором, насамперед компаніями соціальних медіа, і громадянським суспільством.

Зазначено, що нормативно-правові акти щодо протидії дезінформації в соціальних мережах мають ураховувати міжнародні вимоги з дотримання прав людини, національні інтереси, а також бізнес-процеси компаній соціальних медіа.

Ключові слова: дезінформація, правовий механізм, соціальні медіа, національна безпека, свобода слова.

\section{Marushchak Anatolii. The preconditions for the legal mechanisms development to combat disinformation in social media in the context of national security: formulation of the problem}

The article deals with the preconditions for the legal mechanisms development to combat disinformation in social media in the context of national security. The conclusion is formulated on the necessity of the development of such mechanisms on the basis of constitutional freedom of speech principle, with legislative definition of the exclusive possible restriction list in social media for the sake of national security.

It is noted that the difference between legal and corporate internal norms of regulation of social media companies directly affects the effectiveness of national interests' protection both in the United States and Ukraine. Because the non-binding provisions of the First Amendment of the US Constitution for private entities determine the orientation of social media companies to make a profit, although the policy of Facebook and Google adheres to the principles of freedom of speech.

In the context of capacity building of the Centre for Countering Disinformation, counteracting disinformation campaigns for national security reasons requires a combination of efforts of the Centre with the national cybersecurity system, and with regulatory bodies of the media, strategic communications units of Ukraine Government in close cooperation with the private sector, primarily social media companies, and civil society. 
It is concluded that compared to the US government, Ukrainian government has broader constitutional preconditions for the national security interests' protection, particularly in connection with Russian Federation aggression. It is noted that regulations on combating disinformation in social networks should take into account international human rights requirements, national interests, as well as business processes of social media companies.

Key words: disinformation, legal mechanism, social media, national security, freedom of speech.

Постановка проблеми. Останніми роками високими темпами розвиваються нові технології та засоби масової комунікації, забезпечуючи переваги для користувачів і суспільства, а також стимулюючи економічне зростання та політичний розвиток країн. Водночас такий прогрес створює можливості для маніпулювання інформацією. Деякі державні й недержавні суб'єкти систематично поширюють дезінформацію, зокрема, через соціальні медіа, прагнучи дестабілізувати суспільство, втрутитися в процеси демократичного управління суверенними державами й радикалізувати населення. Безумовно, подібна діяльність підриває національну безпеку держав і міжнародну стабільність.

Правові й організаційні механізми протидії кіберзагрозам, які (механізми) розбудовуються в Україні та інших державах світу, лише частково можуть бути застосовані в контексті заходів з протидії дезінформації. Наприклад, у частині державноприватного партнерства з кібербезпеки та кіберзахисту.

Однак між кібератаками й дезінформаційними кампаніями (або операціями) як частинами гібридної війни існують міцні зв'язки. Кампанії з дезінформації в поєднанні з кібератаками на критичну інфраструктуру можуть і завдають фізичної шкоди, поширюють недовіру до органів державного управління та послаблюють демократичні інституції. У контексті інформаційного протиборства нова Стратегія кібербезпеки України підтверджує поєднання «деструктивних дій у кіберпросторі та інформаційно-психологічних операцій», «використання кібератак як інструменту спеціальних інформаційних операцій, маніпулювання суспільною думкою, впливу на виборчі процеси» [1].

Онлайн-кампанії 3 дезінформації були й залишаються найбільш задіяним інструментом Росії в анексії Криму та у військовій кампанії на сході України. Подібне російське втручання відмічене на вибо- pax у США у 2016 році, тоді як між діями натовпу в Капітолії в січні 2021 року й тактикою Росії 2014 року під час захоплення будівлі парламенту в Криму та урядових приміщень на сході України була помітна схожість.

Нещодавно кампанії дезінформації, що проводилися 3 використанням соціальних медіа, безпосередньо вплинули на політичні процеси, включаючи вибори, у різних державах, завдали шкоди системам охорони здоров'я в усьому світі тощо. Окремі соціальні медіа сьогодні стали майданчиком для суспільних дебатів у більшості демократичних країн світу, але також створили середовище, де кампанії дезінформації загрожують таким дебатам.

Створення в Україні Центру протидії дезінформації [2] і розбудова його спроможностей в умовах наявних загроз інформаційній безпеці держави вимагає поглибленого аналізу відповідних теоретико-правових основ з урахуванням фундаментальних принципів свободи думки і слова.

Результати аналізу наукових публікацій свідчать про те, що питання інформаційної безпеки були предметом досліджень багатьох українських учених, а саме: О. Довганя, В. Остроухова, В. Панченко, В. Петрова, В. Пилипчука, В. Польового, О. Розвадовського, Є. Скулиша, Т. Ткачука, О. Юрченка й інших.

Дезінформація була викликом задовго до появи соціальних медіа. у 1934 році Л. Преус указує на «інтенсивні кампанії ворожої та підривної пропаганди проти територіальної цілісності й політичного порядку іноземних держав» [3].

Останнім часом питання протидії дезінформації в соціальних медіа все частіше стають предметом досліджень зарубіжних науковців, особливо тому, що соціальні медіа чи інші посередники «на перехресті комерції, суспільства і навіть політики ... все більше привертають увагу національних урядів, які прагнуть регулювати те, що 
відбувається в їхніх межах» [4]. Передумови для онлайн дезінформації та основні механізми ї̈ поширення досліджували А. Марвік та Р. Льюїс [5], К. Лангвардт [6], Б. Бреннен [7], Н. Янкович [8] та інші дослідники.

Однак у цілому питання формування правових механізмів протидії дезінформації в соціальних медіа було предметом наукових досліджень лише фрагментарно.

Метою статті $\epsilon$ розкриття передумов для формування правових механізмів протидії дезінформації в соціальних медіа в контексті національної безпеки на прикладі України та США.

Виклад основного матеріалу. Протидія дезінформації та нейтралізація ії негативних наслідків для національної безпеки держав безпосередньо залежить від гарантій свободи слова, а також захисту конфіденційності. Держави насамперед мають забезпечити, щоб засоби масової інформації були вільні від злісного втручання й при цьому громадянське суспільство брало участь у публічному обговоренні без дезінформації, запровадивши механізми, що відрізняють правду від вигадки. Розширення можливостей неупередженої участі громадян у громадських справах, включаючи вибори, референдуми тощо, зробить демократії США та України більш стійкими.

Однак завдання протидії дезінформації ускладнюється тим фактом, що в демократичних суспільствах законодавство значно відстає від інновацій, які впроваджують нові технології, через необхідність прийняття консенсусних рішень і нерідко відсутність належної технічної експертизи в законотворців.

Зі зростанням впливу нових технологій на свободу вираження поглядів Д. Балкін ще у 2009 році відзначав, що «найважливішими рішеннями, що впливають на ... свободу слова, будуть ... рішення щодо технологічного дизайну, законодавчих та адміністративних правил, формування нових бізнес-моделей і колективну діяльність кінцевих споживачів» [9].

Сучасний «трикутник» щодо свободи слова (національні держави, КСМ та користувачі) проаналізований Р. Гамільтон у контексті відповідальності за створення й застосування правил у рамках «глобаль- ної публічної площі» [10], якою дослідниця називає сучасні соціальні медіа. Ï̈̈ робота встановлює правомірні винятки з принципу свободи слова з огляду на питання забезпечення національної безпеки, а також розкриває наявну практику модерації контенту соціальними медіа, зокрема, у контексті боротьби з дезінформацією в контексті захисту свободи слова. Р. Гамільтон пропонує власні підходи для посилення боротьби з дезінформацією, зберігаючи при цьому свободу вираження поглядів і вільну ринкову конкуренцію в епоху цифрових технологій [10].

Визначення й закріплення в законодавстві правомірних способів подолання дезінформації в мережах соціальних медіа в контексті захисту національних інтересів, $\epsilon$ частиною дебатів у США, Україні й в інших державах щодо способів і повноважень державних органів у регулюванні відносин, що виникають при використанні соціальних мереж. Беручи до уваги нещодавнє модерування компаніями соціальних медіа (далі - КСМ) висловлювань політиків в Інтернеті, розрив у правових і внутрішньокорпоративних нормах регулювання діяльності КСМ безпосередньо впливає на ефективність захисту національних інтересів як США, так й України. Складність проблеми також посилюється еволюцією можливостей дезінформації, викликаної технологіями «глибоких підробок» (deep fakes), створених із застосуванням штучного інтелекту.

Формування правових механізмів протидії дезінформації в соціальних медіа в контексті національної безпеки має здійснюватися на основі фундаментального конституційного принципу свобода слова із законодавчим закріпленням виключного переліку винятків задля забезпечення національної безпеки з урахуванням Загальної декларації прав людини [11], Міжнародного пакту про громадянські та політичні права [12] та інших міжнародно-правових документів. Соціальні медіа не $\epsilon$ традиційними, тому їх регулювання знаходиться на початковій стадії, змінюється залежно від національних підходів різних держав.

Демократичні держави конституційно гарантують громадянам доступ до інформації та свободу слова, завдяки яким 
забезпечується безкоштовна й справедлива участь громадян у політичних та інших суспільних процесах.

Й американська, й українська конституції визнають статтю 19 Міжнародного пакту про громадянські та політичні права. Право людини на вільне вираження свого погляду, зокрема свободу шукати, одержувати й поширювати будь-яку інформацію та ідеї незалежно від державних кордонів усно, письмово чи за допомогою друку або художніх форм вираження чи іншими способами на свій вибір, може бути, «пов'язане з певними обмеженнями, які ... мають установлюватися законом і бути необхідними: а) для поважання прав і репутації інших осіб; б) для охорони державної безпеки, громадського порядку, здоров'я чи моральності населення [12, ст. 19]. Таке формулювання майже ідентично закріплено в Конституції України. Остання передбачає: «Здійснення ... прав (на свободу думки та слова) може бути обмежене законом в інтересах національної безпеки ... [13, ст. 34]. Більше того, Конституція України визначає, що «захист суверенітету і територіальної цілісності України, забезпечення ії... інформаційної безпеки є найважливішими функціями держави, справою всього Українського народу» [13, ст. 17].

Конституція США й судова практика не $\epsilon$ достатньо послідовними в застосуванні та тлумаченні обмежень свободи слова. Перша поправка Конституції США (у частині свободи слова та преси) поширюється лише на закони, прийняті Конгресом, і на місцеві, державні чи федеральні державні органи [14], але не до дій приватних КСМ. Практика Верховного суду США щодо свободи слова у сфері національної безпеки має прецедент із розгляду спроби уряду заборонити друк публікації секретних документів, що стосуються війни у В'єтнамі [15], хоча Суд відхилив зазначену спробу, однак більшість суддів погодилися, що за певних обставин попереднє обмеження публікації може бути конституційним [16].

Важливість свободи слова для законодавства, політики та культури США може бути підтверджена формулюванням у спільному огляді декількох урядових органів США щодо оцінки загрози домашнього насильницького екстремізму, у якому (огляді) «не оцінюються дії осіб, зайнятих виключно діяльністю, захищеною Першою поправкою (Конституції США - додано авт.) чи іншими правами відповідно до Конституції США» [17]. Цей приклад указує, наскільки життєво важливим, але іноді занадто чутливим задля охорони правопорядку й інтересів національної безпеки $\epsilon$ правове регулювання свободи думки та слова в США, у тому числі щодо висловлювань у мережі Інтернет.

Таким чином, порівняно з урядом США український уряд має більш широкі конституційні передумови для захисту інтересів національної безпеки, зокрема з тимчасовим обмеженням фундаментальної свободи слова. 3 огляду на агресію Російської Федерації з використанням деструктивних дій у кіберпросторі й інформаційно-психологічних операцій, зокрема, і в соціальних медіа, доцільність урегулювання заходів протидії дезінформації $\epsilon$ життєво необхідною.

Безумовно, кампанії дезінформації підривають демократичні процеси, однак як в Україні, так і в США має бути започаткована суспільна дискусія щодо передумов обмеження свободи думки та слова в інтересах національної безпеки й, відповідно, формування прозорого правового механізму правозастосування в кожному конкретному випадку. Сьогодні такі механізми однозначно будуть різними для України та США з огляду на відмінні підходи до обмеження свободи слова в інтересах національної безпеки в правових системах двох держав.

На прийняття остаточних рішень у США стосовно заходів протидії дезінформації (зокрема, і на рівні окремих штатів) у соціальних мережах мають вплив міжнародні аспекти. Так, наприклад, у США відбувається дискусія стосовно судового рішення Суду ЄC (European Court of Justice) Шремс II (Schrems II), яким визнано недійсним Щит конфіденційності приватних даних між ЄС і США (Privacy Shield Decision). Крім того, транснаціональні соціальні мережі розглядають можливість упровадження шифрування даних, що унеможливить не тільки заходи з протидії дезінформації, а й протидію злочинності проти неповнолітніх, терористичні 
прояви тощо. Насамкінець правовий підхід США й інших демократій до КСМ нині базується переважно на саморегулюванні їхньої діяльності в межах розроблених політик обробки даних і користування сервісами.

Іншим складним юридичним питанням $\epsilon$ відповідальність КСМ у контексті свободи слова та законодавства, що застосовується до поширення дезінформації.

Складність застосування імперативних норм до КСМ, які переважно мають головні офіси в США, випливає насамперед з незобов'язуючих норм Першої поправки Конституції США для приватних суб'єктів. Незважаючи на те що політика Facebook i Google, наприклад, передбачає дотримання принципів свободи слова, основною метою цих компаній усе ж залишається отримання прибутку. Отже, чим більшу увагу користувачів приділяють платформи соціальних мереж, тим більший прибуток від реклами можна отримати. Повідомлення про дезінформацію часто, як правило, поширюються більше, ніж перевірена фактами інформація, що потенційно може бути стимулом для КСМ отримувати вигоду від розповсюдження фейків, які законодавством не визначені як незаконна інформація. Як правильно зазначає М. Амморі, держави повинні встановити «значення технологічних компаній у контексті питань свободи слова» [18]. Тому майбутні нормативно-правові акти щодо протидії дезінформації в соціальних мережах мають ураховувати міжнародні вимоги з дотримання прав людини, національні інтереси, а також бізнес-процеси КСМ. Не заглиблюючись у стимули КСМ, можна зробити висновок, що держави все ще мають унікальні повноваження щодо забезпечення основних прав людини та громадянина й регулювання законних випадків їх обмеження на основі інтересів національної безпеки.

Крім того, проблема юрисдикції даних, яка активно дискутується стосовно кібервідносин, $\epsilon$ важливою й для формування правових механізмів протидії дезінформації в соціальних медіа. На початку 2000 року в Google стверджували, що основою для визначення юрисдикції було розташування сервера, на якому знаходяться дані [19]. Однак Д. Даскал дійшла висновку, що «настав час переключити увагу 3 розташування даних на місце розташування та національність об'єкта атаки для визначення юрисдикції правоохоронних органів щодо даних» [20]. Аналогічно акцент доцільно робити на «змістовій спрямованості» дезінформаційних повідомлень задля визначення юрисдикції органів державної влади України чи США.

Насамкінець звернемо увагу на можливості співпраці між США й Україною у сфері протидії дезінформації. Як зазначається в Тимчасовому стратегічному керівництві США з питань національної безпеки, США «будуть співпрацювати разом із союзниками та партнерами для боротьби з новими загрозами, спрямованими на демократію, починаючи від транскордонної агресії, кібератак, дезінформації та цифрового авторитаризму до інфраструктури й енергетичного примусу» [21]. Двосторонній кібердіалог між США та Україною, започаткований у 2017 році, забезпечує основу для подальших спільних зусиль щодо протидії дезінформації. Як визначено в Законі про співробітництво в галузі кібербезпеки України від 2017 року, політика США полягає в тому, щоб «покращити здатність України реагувати на підтримувані Росією дезінформаційні та пропагандистські зусилля в кіберпросторі, у тому числі через соціальні медіа та інші засоби масової інформації» [22].

Висновки. Підсумовуючи викладене, зазначимо, що здійснений аналіз дав підстави для таких висновків стосовно формування правових механізмів протидії дезінформації в соціальних медіа в контексті розбудови спроможностей Центру протидії дезінформації.

Протидія дезінформаційним кампаніям з міркувань національної безпеки вимагає поєднання зусиль зазначеного Центру як із суб'єктами національної системи кібербезпеки, так і з органами регулювання діяльності ЗМІ, підрозділами стратегічних комунікацій органів державної вади України в тісній співпраці з приватним сектором, насамперед КСМ, і громадянським суспільством.

Формування правових механізмів протидії дезінформації в соціальних медіа в контексті національної безпеки має здійснюватися на основі конституційних 
принципів свобода думки і слова із законодавчим закріпленням виключного переліку їх можливого обмеження в соціальних медіа задля забезпечення національної безпеки. Відповідні правові механізми будуть різними для України та США у зв'язку з різними підходами до обмеження свободи слова в інтересах національної безпеки.

Відмінність між правовими та внутрішньокорпоративними нормами регулювання діяльності КСМ безпосередньо впливає на ефективність захисту національних інтересів як США, так й України. Незобов'язуючі норми Першої поправки Конституції США для приватних суб'єктів зумовлюють орієнтацію КСМ на отримання прибутку, хоча політика Facebook i Google, наприклад, і передбачає дотримання принципів свободи слова.

Порівняно з урядом США український уряд має більш широкі конституційні пере- думови для захисту інтересів національної безпеки, зокрема з тимчасовим обмеженням свободи думки і слова. Агресія Російської Федерації актуалізує необхідність посилення заходів протидії дезінформації в Україні.

Таким чином, майбутні нормативноправові акти щодо протидії дезінформації в соціальних мережах мають ураховувати міжнародні вимоги з дотримання прав людини, національні інтереси, а також бізнес-процеси КСМ. Саме держави, а не КСМ мають суверенні повноваження щодо забезпечення основних прав людини та громадянина й регулювання законних випадків їх обмеження на основі інтересів національної безпеки.

Перспективами подальших наукових пошуків визначаємо питання корпоративного регулювання і практики діяльності КСМ задля протидії дезінформації.

\section{ЛITEPATУРА:}

1. Про Стратегію кібербезпеки України : Рішення Ради національної безпеки і оборони України від 14 травня 2021 року, уведене в дію Указом Президента України від 26 серпня 2021 року № 447/2021. URL: https://www.president.gov.ua/documents/4472021-40013.

2. Положення про Центр протидії дезінформації, затверджене Указом Президента України від 7 травня 2021 року № 187/2021. Офіційний вісник Президента України. 2021. № 15. Ст. 774.

3. Preuss L. International Responsibility for Hostile Propaganda against Foreign States. American Journal of International Law. 1934. № 28(4). P. 649-668.

4. Anupam Chander. Internet Intermediaries as Platforms for Expression and Innovation. Glob. Commission on Internet Governance. 2016. № 42.

5. Alice Marwick and Rebecca Lewis. 2017. Media Manipulation and Disinformation Online. Report. Data \& Society Research Institute. URL: https://datasociety.net/output/mediamanipulation-and-disinfo-online/.

6. Kyle Langvardt. Regulating Online Content Moderation, Georgetown Law Journal. 2018. Vol. 106. Issue 5.

7. Bonnie Brennen (2017), Making Sense of Lies, Deceptive Propaganda, and Fake News. Journal of Media Ethics. 2017. № 3. P. 32.

8. Jankowicz N. The Only Way to Defend Against Russia's Information War, The New York Times. 2017. Sept. 25. URL: https://mobile.nytimes.com/2017/09/25/opinion/the-only-way-todefend-against-russias-informationwar.html.

9. Jack M. Balkin. The Future of Free Expression in a Digital Age, 36 Pepp. L. Rev. 2009. Iss. 2. URL: https://digitalcommons.pepperdine.edu/plr/vol36/iss2/9.

10. Hamilton, Rebecca J., Governing the Global Public Square (March 25, 2020). Harvard International Law Journal. 2021, American University, WCL Research Paper № 2020-17. URL: https://ssrn.com/abstract=3426544.

11. Загальна декларація з прав людини від 10.12.1948. URL: https://zakon.rada.gov.ua/ laws/show/995_015\#Text.

12. Міжнародний пакт про громадянські та політичні права від 16.12.1966. URL: https:// zakon.rada.gov.ua/laws/show/995_043\#Text.

13. Конституція України. URL: https://zakon.rada.gov.ua/laws/show/254\%D0\%BA/96\%D0\%B2\% D1\%80\#Text. 
14. Herbert v. Lando, 441 U.S. 153, 168 n. 16 (1979).

15. New York Times Co. v. United States, 403 U.S. 713 (1971).

16. Constitution annotated. Amdt1.2.2.3 Procedural Matters and Freedom of Speech: Prior Restraints. URL: https://constitution.congress.gov/browse/essay/amdt1-2-2-3/ALDE_00000396/ \# essay-14.

17. ODNI, the Department of Justice, and the Department of Homeland Security recently released an unclassified summary of a joint comprehensive threat assessment of domestic violent extremism. March 1, 2021. URL: https://www.intel.gov/assets/documents/702\%20Documents/ declassified/UnclassSummaryofDVEAssessment-17MAR21.pdf.

18. Marvin Ammori, The "New" New York Times: Free Speech Lawyering in the Age of Google and Twitter, 127 HARV. L. REV. 2259 (2014).

19. Erika Morphy (Aug. 24, 2006), Google, Brazil Lock Horns Over Social Networking Data, Tech News World. URL: http://www.technewsworld.com/story/privacy/52624.html.

20. Jennifer Daskal. Whose Law Governs in a Borderless World? URL: https://constitutioncenter.org/ digital-privacy/whose-law-governs-in-a-borderless-world\#footnote-24.

21. Interim National Security Strategic Guidance. URL: https://www.whitehouse.gov/ wp-content/uploads/2021/03/NSC-1v2.pdf. March 2021.

22. Ukraine Cybersecurity Cooperation Act of 2017, 115 H.R. 1997, 2018 H.R. 1997, 115 H.R. 1997. April 6, 2017. 